\title{
Optimum Arrangement of Photovoltaic Systems in Housing at Khartoum: Application of Renewable Energy in Urban Design
}

\author{
Zeinab Abdallah M. Elhassan, ${ }^{1}$ Muhammad Fauzi Mohd Zain, ${ }^{1}$ Kamaruzzaman Sopian, ${ }^{2}$ \\ and A. A. Abass ${ }^{1}$ \\ ${ }^{1}$ Department of Architecture Engineering, Faculty of Engineering and Built of Environment, University Kebangsaan Malaysia, \\ Selangor Darul Ehsan, 43600 Bangi, Malaysia \\ ${ }^{2}$ Department of Mechanical and Material Engineering, University Kebangsaan Malaysia, Selangor Darul Ehsan, \\ 43600 UKM Bangi, Malaysia
}

Correspondence should be addressed to Zeinab Abdallah M. Elhassan, zeinab3007@yahoo.com

Received 15 February 2011; Accepted 13 December 2011

Academic Editor: Mike Raco

Copyright ( $) 2011$ Zeinab Abdallah M. Elhassan et al. This is an open access article distributed under the Creative Commons Attribution License, which permits unrestricted use, distribution, and reproduction in any medium, provided the original work is properly cited.

\begin{abstract}
This paper searches to find out of building integrated photovoltaic system designs in Khartoum. It discussed technical issues and designed an integrated of photovoltaic in domestic using, within an urban approach towards sustainability in energy. Photovoltaic systems can be used to develop the solar energy in almost all kinds of applications. Exploiting of solar energy for domestic use is one avenue where the energy produced from the sun is converted into electricity to power most if not all the appliances available at our homes and residences. Building a photovoltaic system is the process of designing, selecting, and calculating the ratings of the equipments employed in the system. This process depends on a range of factors such as geographical location, solar irradiation, and load requirements. I introduce the procedures utilize, in building and selecting the equipments of a grid-connected photovoltaic system based on the Watt-hour demand of $3.8 \mathrm{kw}$. As a case study, a residence in Khartoum with low-energy consumption is selected.
\end{abstract}

\section{Introduction}

Building integrated photovoltaics (BIPVs) is a PV application close to being capable of delivering electricity at less than the cost of grid electricity to end users in certain peak demand niche markets [1]. BIPV acceptance varies seriously by, and within, country depending upon climate, built environment, electricity industry structure, government policies, local product offerings, market stimulation mechanisms, consumer demand, existing industrial capabilities, and the forms of tariff arrangement for grid-connected PV power generation [2-6].

BIPV grid-connected system involves combining solar photovoltaic electricity technologies with those of building construction [7]. This subject is of great interest to those in the fields of energy conservation and building design, however, cannot be underestimated in the context of the more familiar notion of sustainable development [8].
The concept of sustainability is more relevant than ever; among support systems used, in sustainable energy, the common used was BIPV [9]. Of the essential aspects, sustainability of energy must become the cornerstone of the researchers' design philosophy. It processes the design of sustainable buildings that rely on renewable resources to provide most, and eventually all, of their own energy need [10]. The most promising renewable energy technology is photovoltaic (PV) power [11]. PV power is a truly elegant means of producing on-site electricity. The important feature which influences of design the sustainable house was climate and solar radiation at the case study location. The climate of Khartoum in the summers is invariably hot (mean max. $41^{\circ} \mathrm{C}$ and mean $\min .25^{\circ} \mathrm{C}$ ) with large variation; low relative humidity averages $25 \%$. Winters can be quite cool. Sunshine is very prevalent. Dust storms occur in summer [12]. The climate is a typical desert climate where rain is infrequent, and annual variation in temperature is large. 
Khartoum is located at 15.38 latitude and 32.28 longitudes. Energy planners have long envisioned large utilityscale solar power plants covering large expanses of land [11]. Khartoum is located at 15.38 latitude and 32.28 longitudes. Energy planners have long envisioned large-utility-scale solar power plants covering large expanses of desert [12]. While this vision has many favorable attributes, the economics require careful investigation. Grid-connected PV systems require the allocation of land [13] which must be acquired and prepared to accept the PV system [14]; the cost of land and the site work must be considerable. In Sudan the lack of available large open tracts of land has effectively precluded the large-scale grid-connected PV system option as afforded to develop in the Sudan renewable energy resources for electricity generation in Sudan [15]. The residential sector consumes upwards of $17 \%$ electrical energy in Sudan. More than $80 \%$ of this is generated using fossil fuels that contribute immensely to environmental pollution and global warming. The use of energy efficient measures and renewable energy, complimenting fossil fuels, can reduce electrical power outages during peak demand and, more importantly, cause a reduction of gaseous pollutants. BIPV can be in the form of (i) roofing materials, (ii) wall and fenestration materials [13], and (iii) flexible photovoltaic modules [13] and can be integrated to the roof of new buildings or where major roof replacement is undertaken. Methods of integration include exchangeable PV shingles, prefabricated PV roof panels, and insulated PV roof panels [13]. Fully integrated BIPV roofing systems must perform the function of a standard roof and provide water tightness, drainage, and insulation. Most retrofitted roof-mounted systems are though not fully integrated into the roof structure [16]. Roofs offer an attractive location for BIPV because of the following.

\section{Procedure of Designs}

This system was designed for maximum output in summer and has an acceptance half-angle of $36^{\circ}$ providing a collection time of $7 \mathrm{~h}$. was characterised experimentally for highlatitude bifacial-cell BIPV applications [16]. Different configurations were made for grid connected, roof integrated, East/West, spring/fall, and wall integration. A cross-section of $\mathrm{a}$ is shown in [16]. It illustrates that the cross-section of roof integrated designed for Stockholm conditions [16]. The highest optical efficiency reported was $56 \%$ for a bifacialbased MaReCo. In contrast, optical efficiency of $91 \%$ was predicted for dielectric-filled BIPV covers [17] and 85\% for an air-filled asymmetric CPC BIPV system [18, 19].

Design will establish the number of modules, the dimensions of the modules, and the total dimensions of the system to be integrated into a roof. In this case is avoided some modules have integrated diodes to make a shortcut when a row of cells are covered or shaded. AC modules also must isolate the impact of shading as each module's, that mean shading was avoided, DC power output is converted to AC and drawn individually with a converter. In this case to get the power which was loaded at the sustainable house [20], photovoltaic technologies, with polycrystalline cells, are less
TABLE 1: System architecture summary.

\begin{tabular}{ll}
\hline Component & Characteristics \\
\hline PV system power & $5 \mathrm{~kW}$ \\
Type of building & $\begin{array}{l}\text { Roofing tile PV } \\
\text { integration and double-glazed PV glass } \\
\text { integration }\end{array}$ \\
Integration & $\begin{array}{l}\text { Monocrystalline silicon } \\
\text { Type of cell }\end{array}$ \\
Technology & $\begin{array}{l}\text { (windows) } \\
34.2 \mathrm{~m}^{2}\end{array}$ \\
Array dimensions polycrystalline silicon cells \\
Weight & $\begin{array}{l}120 \mathrm{~kg} \text { (double-glazed PV glass) } \\
\text { Line Back FX (Nihon Den chi Co. Ltd.) }\end{array}$ \\
Inverter & $\begin{array}{l}4.5 \mathrm{kVA} \\
\text { Horizontal pyrheliometer, inclined } \\
\text { pyrheliometer, air temperature }\end{array}$ \\
Monitoring &
\end{tabular}

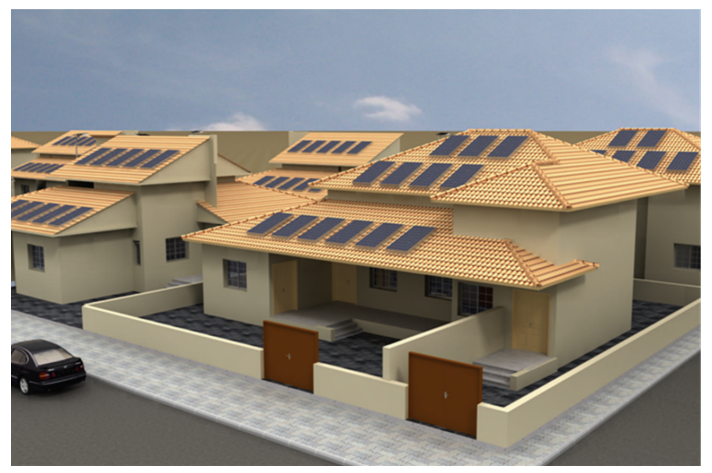

Figure 1: Installation photovoltaic module.

impacted by irregular shading effects, due to different electrical connection characteristics and better performance in low light. Inverter characteristics are also critical, since most have a cut-off point. In general, shading should be avoided. A fully integrated single house design item [22]. Although the architect may be creative, decisions are needed from the start, in particular, [21] from structural and building services engineers and to get information and ideas about energy and comfort systems and structural design, with all technical requirements as shown in Table 1. Designs at Alazhari city in Khartoum State converting sunlight into electricity through the use of PV cells as part of integrated building systems are an appropriate way of accessing renewable energy. The PV conversion process is silent, has no moving parts, and is pollution-free. The slope angle $(\beta)$ with the roof is defined as the angle between the plane of the solar collector in question and the horizontal as shown in Figure $1,(\beta)$ is positive, the orientation of the surface is toward the equator, and, when negative, it is toward the pole [23]. The optimum design of a BIPV system, although based on a building's electrical load profile, PV output, and balance-of-system characteristics, must be cognoscenti of building design constraints, building location, offset costs, climate, and future load growth [4]. System economic viability depends on local electrical loads and utility prices $[24,25]$. Approximately 25-30\% [26] of 


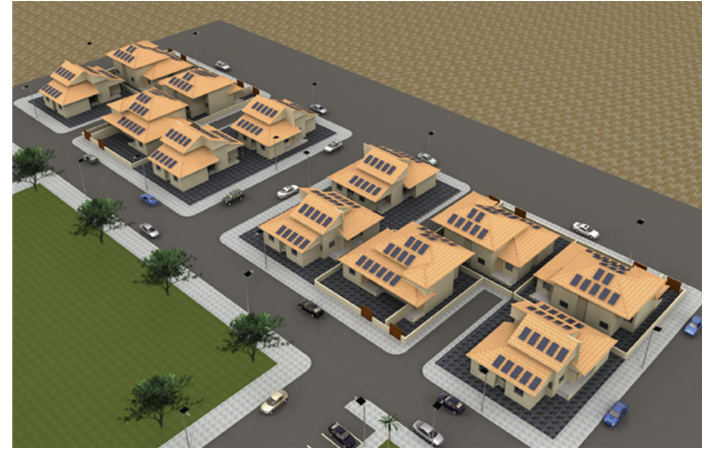

FIGURE 2: Planning of residence in Khartoum.

energy consumed in buildings in industrialised countries is as electricity. Photovoltaics can be integrated on virtually every conceivable structure from bus shelters to high-rise buildings. BIPV modules fabricated directly onto building materials can, in high-volume production, lead to lower substrate, distribution, and installation costs [27].

\section{Results and Discussion}

Design of (BIPV) house in khartoum of $3.8 \mathrm{~kW} /$ day depends mainly on installing PVC panels in italics ceilings (Bungalow) and connection of batteries with internal network of solar house, in addition to that home connection with the national electricity network to allow some part of the house to use public network electricity, and the other part could use PVC electricity. At slope $\beta 23^{\circ}$ in Figure 1 shows the position of the sun at solar noon, a PV panel oriented to the north and titled at the slope of roof $[28,29]$. The direction of North and South with $\beta 23^{\circ}$ is restricted fully ventilated in the State of Khartoum. Of the location, this deals with [20] that obtained considered the roof-top mounting system as on-roof mounting, leaving the existing roofing material in place, and in-roof mounting, where the modules take over the function of the roof tiles that obtain the position of system and the tilt of roof was influence of the successful capture the solar radiation and functional architecture design as [20] resulted.

3.1. Installation of Orientation of Modules and the Roof. The roofs were directed towards the East inclined to North direction [29]. The sun in Sudan in most hours of day represents the capacity that will allow the solar panels work since it was sunrise and 12:30 pm in summer until 1:30 pm in winter, sun direction is towards east then changed direction from 12:30 pm in summer and 1:30 pm in winter until sunset towards the west $[22,31]$ deals with this result that obtained that the optimum time to get maximum power was 121:30 as optimum time to capture most of solar radiation depend on the result of solar radiation as shown in Figure 2, according to geographical mandate studies of Khartoum state, the roofs were directed towards east and west with an incline [19]. The geographical location of the Gaza Strip makes it one of the relatively sun-rich regions in the globe. It is located in the northern hemisphere area of the earth at $31.3^{\circ}$ latitude and $34.3^{\circ}$ longitude with an annual incident solar irradiance of about $2000 \mathrm{~kW} \cdot \mathrm{m}^{-2}$ [13]. This implies that the solar panel must be mounted facing the south to capture a maximum amount of solar energy, and the number of days of autonomy, where the system will operate without receiving an input charge from the sun, is approximated to 4 days according to the record $[9,32]$. The minimum and maximum power generated values are obtained from historical data, and their effect on demand is also studied. The loss of load hours is calculated considering the power generation and load requirement of different months, with a different locations. That means the optimum angle of slope of roof was $23.5^{\circ}$ at the Khartoum location to get the maximum power; the status of each of those considerations must be included in the design models for BIPV [15]. The single house contains the different activities of normal housing, as the bedroom, living room, a reception, and a small kitchen serving medium and large family depending on the model, ranging from that of two rooms and a reception for men, another for women, and various bathrooms, and the largest model in three sleeping rooms and reception for men, another for women and various bathrooms. Those activities' load was $3.8 \mathrm{~kW} /$ day as results found shown in Figure 2 for different appliances for single home user load. It has been found that for this system each home user consume energy around ( $224 \mathrm{~W} /$ day of Wh/day) with a peak demand nearly as shown in Table 1 . The system also gives the opportunity for expanding its capacity in order to manage with the increasing demand in the future [33]. This was done by increasing either the rated power of diesel generator, renewable generator, or both of them [34]. As [20] found, the maximum load was 4.8 in Gaza and [35]. This mode of operation is particularly suitable for systems with relatively small renewable energy penetrations that obtained the size of the system in small sizing of renewable energy using BIPV depending on the load and suitability of whole system component. PV system was positioned upon the roof and distant from the first PV modules and was thought to be appropriate over the life of the building when other PV subarrays will be positioned much closer to it $[35,36]$. It was also thought that more space for PV equipment became necessary because the area was approximately $40 \mathrm{~m}^{2}$ required for standard equipment in the system design in this case, and approximately $10 \mathrm{~m}^{2}$ of additional space is required for PV-related equipment. Thus, the PV plant floor area is about $4-5 \%$ of the total array area $[35,36]$ found as the result the issues in optimizing the use of isolated small PV power generation in remote areas and revealed the procedure to evaluate different PV method considering the stochastic nature of the insulation, and the load requirement, which acquires the installation of the grid-connected system, has a most important command factor of evaluate the success which is the construction way and the functional design.

3.2. Design the Array. The researcher designed the array based on architecture design of the house and upon the roof as two parts of array, 20 modules of one part, have contact with the other part with same number of this module, after running at software, we found that the plane irradiance was $1000 \mathrm{w} / \mathrm{m}^{2}$ as [36]. 
For the section of this array (with 20 module), the output power was $3.8 \mathrm{~kW}$, which meant the output of power was appropriate with the design of electricity requirement that validated that the selection of the type of module and array was sufficient to generate the power which was needed for the design, with all requirement, slope of angles and orientation, and the system component design.

3.2.1. Sizing of the Solar Array and System Design at Alazhari City. To avoid the risk of under sizing, we begin by dividing the total average energy demand per day by the efficiencies of the system components to obtain the daily energy requirement from the solar array:

$$
\begin{aligned}
E_{\text {array }} & =\frac{\text { daily average energy consumption }}{\text { product of component efficiencies }} \\
& =\frac{3500}{0.9 \times 0.8 \times 0.8}=3.8 \mathrm{~kW} \cdot \text { day }^{-1} .
\end{aligned}
$$

Then the peak power is

$$
\begin{aligned}
P_{p} & =\frac{\text { daily energy requirement }}{\text { minimum peak sun }- \text { hours per day }} \\
& =\frac{5173}{3.84}=1508 \mathrm{~W} .
\end{aligned}
$$

The total current needed for a DC voltage of 24 is $I=$ $1608 / 24=67$. A and according to the selected panel KC50T (http://www.kyocerasolar.com/pdf/specsheets/KC50T.pdf).

The number of series panels, $N s=24 / 24=1$, and the number of parallel panels, $N p=67 / 7.45=40$, are approximated to 40 which means that the number of panels needed is $(2 \times 20)$, also [20] designs the array and the number of module depends on their load requirement that means the sizing of module depend on the factors that affect system sizing. It is to be noted that an average efficiency of $12 \%$ was assigned to the PV modules used in the present installation, while doing the above calculation.

3.2.2. Sizing of the Battery Bank. The amount of energy storage required $=4500 \times 4=18 \mathrm{~kW}$, where the number 4 represents the number of days. For safety, estimate the previous value by permissible level of discharge MDOD (75\%):

$$
\begin{aligned}
E_{\text {safe }} & =\frac{\text { required energy storage }}{\text { maximum depth of discharge (MDOD) }} \\
& =\frac{18000}{0.75}=24 \mathrm{~kW} .
\end{aligned}
$$

The capacity of the battery bank in ampere-hours required assuming that we have selected a battery voltage of $12 \mathrm{~V}$ is $C=24000 / 12=2000 \mathrm{Ah}$, and, according to the selected battery (UB-8D AGM, $250 \mathrm{AH}, 12 \mathrm{~V}-\mathrm{DC}$ ), the number of batteries needed is $N$ batteries $=2000 / 250=8$ batteries. With DC voltage of $24 \mathrm{~V}$, four parallel branches are recognized according to the equation $N p=8 / 2=4$. Each branch contains 2 series batteries.

3.2.3. Sizing of the Voltage Regulator. The total current required $I=9 \times 8.03 \times 1.25=90.34 \mathrm{~A}$, where the current $I_{\mathrm{sc}}$ for each of the selected modules equals $8.03 \mathrm{~A}$ and a safety factor of 1.25 is used. The number of regulators required is $N=90.34 / 60=1.5$ approximated to 2 (Xantrex C-60, 24-V, 60-A) [20].

3.2.4. Sizing of the Inverter. The power of appliances that may run at the same time is given by the following $P=(10 \times 11+$ $125+200+1000)=1435 \mathrm{~W}$, and the appliances with large surge currents that include motors are $245 \times 3=735 \mathrm{~W}$. To allow the system growth, we add $25 \%$ of the previous two values to get total power:

$$
\begin{aligned}
& p_{\text {total }}=(\text { power of appliances running simultaneously } \\
& \text { +power of large surge current appliances), } \\
& p_{\text {total }}=(1435+735) 1.25=2712 \mathrm{~W}=27.12 \mathrm{~kW} \text {. }
\end{aligned}
$$

The inverter needed must be able to handle about $2712 \mathrm{~W}$ 220 Vac. Electronics inverter, LS-3024, $3000 \mathrm{~W}, 24 \mathrm{Vdc}$, $220 \mathrm{Vac}$, proper sine-wave, with a half-hour rating of $3700 \mathrm{~W}$ and surge power of $9000 \mathrm{~W}$ for 5 seconds is a good choice [20]. Sizing of the System means proper cabling type and the performance of a photovoltaic system. The graph shows that the circuit diagram shows a region with a photovoltaic generator. The DC wires between the photovoltaic modules and batteries through the voltage regulator must withstand the maximum current produced by these modules.

This current is given by $\mathrm{Im}=9 \times 8.03 \times 1.25=90.34 \mathrm{~A}$. The optimum wire type for this current is copper wires (AWG), while the AC wire from the inverter to the electric panel of the residence must withstand the maximum current produced by the inverter output. This current is given by the following formula for a rated AC voltage of $220 \mathrm{~V}$ : Im = $3000 /(220 \times \mathrm{pf})=17.04 \mathrm{~A}$ at a power factor of 0.8 . An optimum wire type for this a current would be 10 copper wires (AWG); in both $\mathrm{AC}$ and $\mathrm{DC}$ wiring the voltage drop is taken not to exceed the $4 \%$ value. It designed the system in accordance with the load requirement of the house at Alazhari city. The selection of inverter which was appropriate for the architecture design the sort inverter by power the number of inverter for one house individually was 1 , and the operation voltage which accepted to this inverter as details of company manufacturing is given by software between $125.44 \mathrm{~V}$ and $550 \mathrm{~V}$. The capacity of inventor power was $3.0 \mathrm{~kW}$ the real voltage was between $125 \mathrm{~V}$ and $440 \mathrm{~V}$.

3.3. Tilt Roof of Building Integrating Photovoltaics. Sloped roof constructions are very common for residential buildings and are most suited for a PV installation if orientated approximately towards the equator. The roof systems are particularly useful for sites situated towards the quarter where overhead sunlight is predominant. Form and color of modules and system cells are typically dark blue in color. Different colors of the type of module also have an impact on color [37]. Frameless modules give a very harmonious impression as the roof is not disturbed by frame patterns of different color or material to that of the cells as shown in Figure $2[38,39]$. Smaller frames in the same color as the cells are almost invisible at the surface. 
3.4. Planning Concern of Installation. The residential sector is composed around a service center, the group of neighborhood housing and which a service center is provided that contains the basic services needed as shown in Figure 2. In [40], planning used that kind of technology in supplying energy as indicated by the figures of design and planning implemented in this paper as the rules of planning. The amount of irradiation in the residence depends on the latitude of the building and the local climate as [40] found to get a perfect design. The maximum irradiation depends on the orientation and the angle of the collection surfaces also put in consider for latitudes $32^{\circ}$ North; good results (over 90 per cent) can be achieved between the Southeast and the Southwest with system tilt angle $23^{\circ}$ as shown in Figure 1. Orientations between East and Southeast and between Southwest and West are acceptable for tilt angle $23^{\circ}$. Those agree with [8] that determined the optimum dimensions of an appropriate stand-alone photovoltaic system, able to guarantee the coverage of remote consumers energy demand located area. A detailed energy balance analysis of selected photovoltaic system was done on an hourly basis $[8,20]$. The equipments used to construct the stand-alone photovoltaic system for the suggested remote residence described above are summarized with some details and specifications in Table 1 which defines his load in Gaza that obtains that the electrical appliances available at the residence are itemized with their power ratings and time of operation during the day to obtain the average energy demand in Watt-hour per day.

3.5. The Constraint and Economics. The life time has been considered to be 25 years and the annual real interest rate has been taken as $4 \%$. As the system has been designed for single and also for multiple home users like 10 to 50, the load consumed by the user is low so operation and maintenance cost has been taken $500 \mathrm{SP} /$ year. There is no capacity shortage for the system and operating reserve is $10 \%$ of hourly load. Analysis shows that the cost of energy (kWh) is low for the system which is the combination of 50 homes [41]. The load demands each combination of homes with system architecture and financial summary [9]. The system simulations showed that with a daily load of $207 \mathrm{~kW} /$ day the combination of a $12 \mathrm{kWp}$ PV system with a battery backup capacity of $108 \mathrm{~kW}$ would be optimum, given the most suitable strategy for the use of two differently sized solar renewable energy generators now present [9] yearly system performance of autonomous photovoltaic energy systems with battery storage and simulated using the predetermined combinations. That mean it was shown that the yearly system performance predicted from the 3-and 4-day synthetic data closely agreed with that obtained from the measured data, varying only slightly for different combinations that obtained the reported development of computer approach for evaluating general performance of grid-connected PV system.

\section{Conclusion}

Design small scale of housing developments is apparent, with whole requirement of urban planning and technical solution of BIPV grid connected system. Design was developed and structure which implement the housing construction process is presented with numerous opportunities for PV roof integration in single-family houses, 10, 20, 50, and for roof integration in the single house. To complete the electricity which provided in Khartoum. This allows for the integration of a many numbers of PV systems during construction. Integration of PV systems in residential homes to generate the maximum power from the system with definite load $3.8 \mathrm{kw} /$ day for a single house in Khartoum, Alazhari city, can be carried out. The designer began to investigate layouts that would maximize solar potential, considering day lighting, passive solar gain, and the use of PV module.

\section{Acknowledgments}

The authors would like to thank Prof. Dr. Muhammad Fauzi Mohd. Zain, for his support, fully accommodating and providing the necessary equipment, and giving the principals of scientific experience in this area, and Prof. Dr. Kamaruzzaman Sopian for providing necessary information about BIPV and software, we express our blessing for all members of SUCOM group for their cooperation.

\section{References}

[1] S. A. Blanton, M. A. Hines, and P. Guyot-Sionnest, "Photoluminescence wandering in single CdSe nanocrystals," Applied Physics Letters, vol. 69, no. 25, pp. 3905-3907, 1996.

[2] M. A. Green, "Crystalline and thin-film silicon solar cells: state of the art and future potential," Solar Energy, vol. 74, no. 3, pp. 181-192, 2003.

[3] G. C. Bakos, M. Soursos, and N. F. Tsagas, "Technoeconomic assessment of a building-integrated PV system for electrical energy saving in residential sector," Energy and Buildings, vol. 35, no. 8, pp. 757-762, 2003.

[4] M. Watt et al., Assessing the Potential for PV in Buildings, 1997.

[5] F. D. J. Nieuwenhout, A. Van Dijk, P. E. Lasschuit et al., "Experience with solar home systems in developing countries: a review," Progress in Photovoltaics: Research and Applications, vol. 9, no. 6, pp. 455-474, 2001.

[6] N. B. Mason, T. M. Bruton, and K. C. Heasman, kWh/kWp Energy Production from LGBG Cell Modules in Northern Europe, Tagungsband des. 12.

[7] J. Schmid, "PV in buildings," in Proceedings of the 1th E. C. Photovoltaic Solar Energy Conference, L. Guimarães, W. Palz, C. De Reyff, H. Kiess, and P. Helm, Eds., pp. 12-16, 1992.

[8] J. K. Kaldellis, P. Koronakis, and K. Kavadias, "Energy balance analysis of a stand-alone photovoltaic system, including variable system reliability impact," Renewable Energy, vol. 29, no. 7, pp. 1161-1180, 2004.

[9] R. M. Moharil and P. S. Kulkarni, "A case study of solar photovoltaic power system at Sagardeep Island, India," Renewable and Sustainable Energy Reviews, vol. 13, no. 3, pp. 673-681, 2009.

[10] S. Beerbaum and G. Weinrebe, "Solar thermal power generation in India - a techno-economic analysis," Renewable Energy, vol. 21, no. 2, pp. 153-174, 2000.

[11] A. Chaurey, M. Ranganathan, and P. Mohanty, "Electricity access for geographically disadvantaged rural communitiestechnology and policy insights," Energy Policy, vol. 32, no. 15, pp. 1693-1705, 2004. 
[12] W. E. Alnaser, F. Trieb, and G. Knies, "Solar energy technology in the Middle East and North Africa (MENA) for sustainable energy, water and environment," Advances in Solar Energy, vol. 17, pp. 261-304, 2007.

[13] T. Markvart, Solar Electricity, John Wiley \& Sons, 2000.

[14] R. Billinton and R. Karki, "Reliability/cost implications of utilizing photovoltaics in small isolated power systems," Reliability Engineering and System Safety, vol. 79, no. 1, pp. 1116, 2003.

[15] A. M. Omer, "Renewable energy resources for electricity generation in Sudan," Renewable and Sustainable Energy Reviews, vol. 11, no. 7, pp. 1481-1497, 2007.

[16] M. Adsten, Solar Thermal Collectors at High Latitudes: Design and Performance of Non-Tracking Concentrators, Acta Universitatis Upsaliensis, 2002.

[17] A. Zacharopoulos, Optical design modelling and experimental characterisation of line-axis concentrators for solar photovoltaic and thermal applications, 2001.

[18] T. K. Mallick, P. C. Eames, T. J. Hyde, and B. Norton, "The design and experimental characterisation of an asymmetric compound parabolic photovoltaic concentrator for building façade integration in the UK," Solar Energy, vol. 77, no. 3, pp. 319-327, 2004.

[19] P. C. Eames, M. Smyth, and B. Norton, "The experimental validation of a comprehensive unified model for optics and heat transfer in line-axis solar energy systems," Solar Energy, vol. 71, no. 2, pp. 121-133, 2001.

[20] A. Abu-Jasser, "A stand-alone photovoltaic system, case study: a residence in Gaza," Journal of Applied Sciences in Environmental Sanitation, vol. 5, no. 1, pp. 81-91, 2010.

[21] A. Zahedi, "Development of an electrical model for a PV/battery system for performance prediction," Renewable Energy, vol. 15, no. 1-4, pp. 531-534, 1998.

[22] T. Markvart, A. Fragaki, and J. N. Ross, "PV system sizing using observed time series of solar radiation," Solar Energy, vol. 80, no. 1, pp. 46-50, 2006.

[23] S. Bari, "Optimum slope angle and orientation of solar collectors for different periods of possible utilization," Energy Conversion and Management, vol. 41, no. 8, pp. 855-860, 2000.

[24] J. D. Mondol, Y. G. Yohanis, and B. Norton, "Optimal sizing of array and inverter for grid-connected photovoltaic systems," Solar Energy, vol. 80, no. 12, pp. 1517-1539, 2006.

[25] T. K. Mallick, P. C. Eames, and B. Norton, Thermo-Optical Analysis of Asymmetric Compound Parabolic Photovoltaic Concentrator for Building Integration in the UK, 2001.

[26] F. Sick and T. Erge, Photovoltaics in Buildings: A Design Handbook for Architects and Engineers, Earthscan/James \& James, 1996.

[27] J. Ji, G. Pei, T. T. Chow et al., "Experimental study of photovoltaic solar assisted heat pump system," Solar Energy, vol. 82, no. 1, pp. 43-52, 2008.

[28] M. Hankins, Solar Electric Systems for Africa: A Guide for Planning and Installing Solar Electric Systems in Rural Africa, Commonwealth Secretariat, 1995.

[29] Deutsche Gesellschaft für Sonnenenergie, Planning and Installing Photovoltaic Systems: A Guide for Installers, Architects and Engineers, Earthscan, 2008.

[30] W. E. Alnaser, B. Eliagoubi, A. Al-Kalak et al., "First solar radiation atlas for the Arab world," Renewable Energy, vol. 29, no. 7, pp. 1085-1107, 2004.

[31] P. W. Stackhouse and C. H. Whitlock, Surface Meteorology and Solar Energy (SSE) Release 6.0 Methodology, NASA SSE 6.0. Earth Science Enterprise Program, National Aeronautic and Space Administration(NASA), Langley, Va, USA, 2009.
[32] B. S. Borowy and Z. M. Salameh, "Optimum photovoltaic array size for a hybrid wind/PV system," IEEE Transactions on Energy Conversion, vol. 9, no. 3, pp. 482-488, 1994.

[33] G. M. Masters and J. Wiley, Renewable and Efficient Electric Power Systems, Wiley Online Library, 2004.

[34] C. V. Nayar, S. J. Phillips, W. L. James, T. L. Pryor, and D. Remmer, "Novel wind/diesel/battery hybrid energy system," Solar Energy, vol. 51, no. 1, pp. 65-78, 1993.

[35] A. Sasitharanuwat, W. Rakwichian, N. Ketjoy, and S. Yammen, "Performance evaluation of a $10 \mathrm{kWp} \mathrm{PV}$ power system prototype for isolated building in Thailand," Renewable Energy, vol. 32, no. 8, pp. 1288-1300, 2007.

[36] R. E. H. Sims, H. H. Rogner, and K. Gregory, "Carbon emission and mitigation cost comparisons between fossil fuel, nuclear and renewable energy resources for electricity generation," Energy Policy, vol. 31, no. 13, pp. 1315-1326, 2003.

[37] M. R. Emmanuel, An Urban Approach to Climate-Sensitive Design: Strategies for the Tropics, Taylor \& Francis, 2005.

[38] J. Benemann, O. Chehab, and E. Schaar-Gabriel, "Buildingintegrated PV modules," Solar Energy Materials and Solar Cells, vol. 67, no. 1-4, pp. 345-354, 2001.

[39] A. N. Celik, "The system performance of autonomous photovoltaic-wind hybrid energy systems using synthetically generated weather data," Renewable Energy, vol. 27, no. 1, pp. 107121, 2002.

[40] G. J. Dalton, D. A. Lockington, and T. E. Baldock, "Feasibility analysis of renewable energy supply options for a gridconnected large hotel," Renewable Energy, vol. 34, no. 4, pp. 955-964, 2009.

[41] S. Roaf and M. Fuentes, Demonstration Project for a $4 \mathrm{KW}$ Domestic Photovoltaic Roof in Oxford, vol. 1, 1999. 


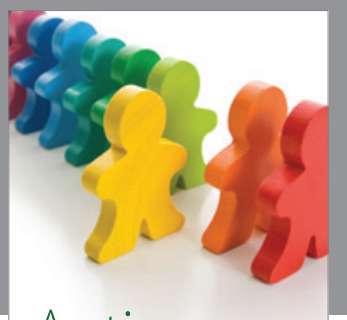

Autism

Research and Treatment
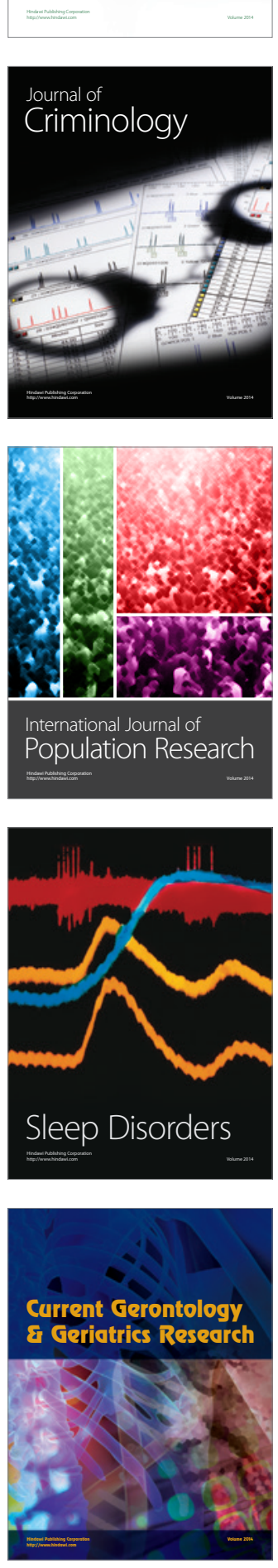
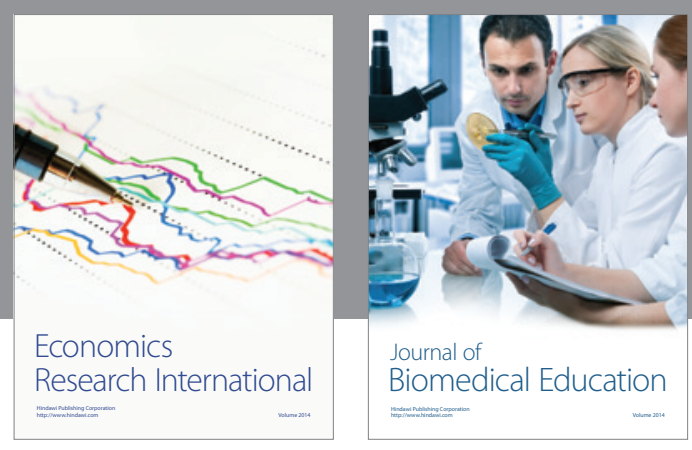

Journal of

Biomedical Education

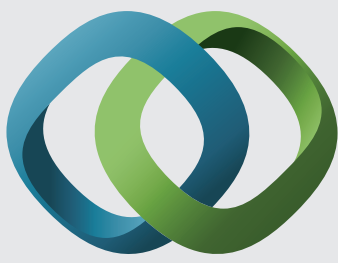

\section{Hindawi}

Submit your manuscripts at

http://www.hindawi.com
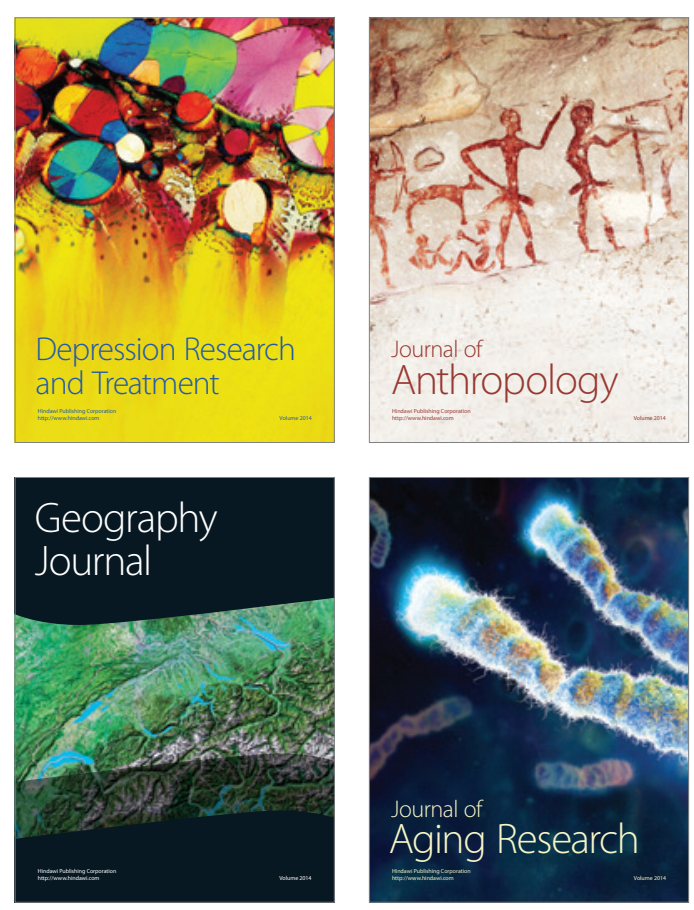

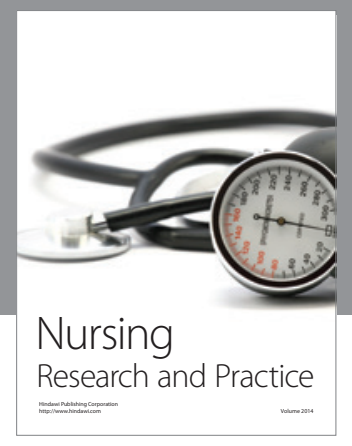

Nursing

Research and Practice

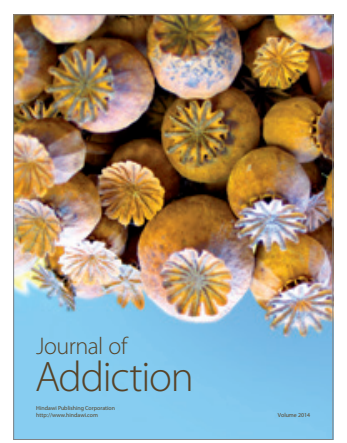

Child Development

Research

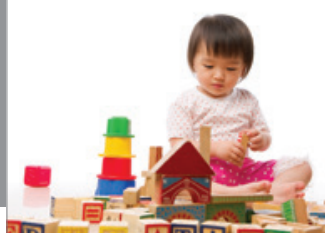

迥
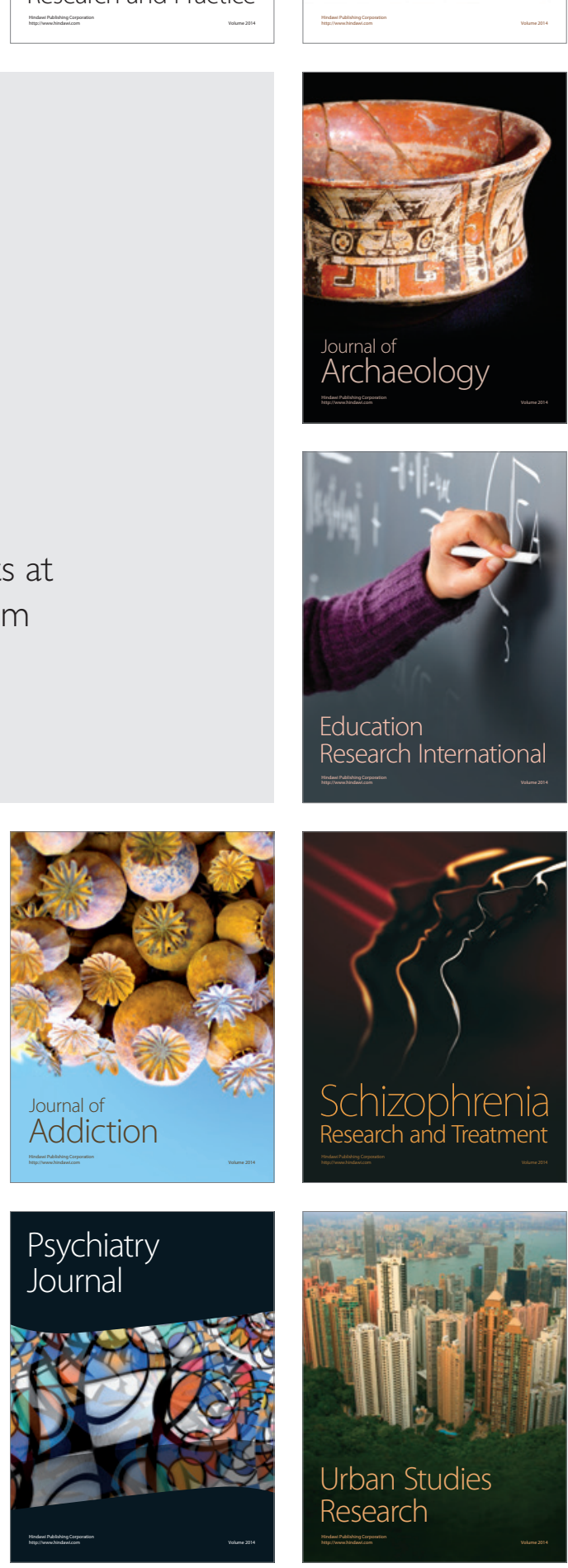